\title{
Religious differences in child vaccination rates in urban Africa: Comparison of population surveillance data from Ouagadougou, Burkina Faso
}

\author{
Abdramane Soura ${ }^{1}$, Gilles Pison ${ }^{2}$, Leigh Senderowicz ${ }^{1}$, Clémentine Rossier ${ }^{1}$ \\ ${ }^{1}$ Ouagadougou Health and Demographic Surveillance System, Institut Superieur des Sciences de \\ la Population, University of Ouagadougou, Burkina Faso \\ 2Institut National d'Etudes Démographiques, Paris, France
}

\begin{abstract}
Many studies have shown a significant relationship between religion and health in Western countries. In developing countries, however, there is a dearth of scientific studies on the matter. Using data from the Ouagadougou Health and Demographic Surveillance System, this paper examines religious differences in child vaccination rates in five districts of Ouagadougou, Burkina Faso. It tests the applicability of the selectivity hypothesis, which holds that religious differences in health come from underlying differences in the socio-economic and demographic composition of religious communities. In our study population, even when socio-economic and demographic characteristics are taken into account, an effect of religion on child vaccination rates was observed. This suggests that religious disparities in child vaccination rates are not solely due to the makeup of different religious communities, but also to ideological differences and/or to diffusion effects from interactions within religious groups. The religious differences demonstrated here suggest that a greater emphasis should be put on community-based approaches involving religious leaders when addressing health disparities.
\end{abstract}

Keywords: Vaccination, religion, child, Ouagadougou, Burkina Faso.

\section{Résumé}

Dans les pays occidentaux, de nombreuses études ont montré une relation significative entre la religion et la santé. Dans les pays en développement par contre, il y a peu d'études scientifiques sur la question. Utilisant des données recueillies dans l'Observatoire de population de Ouagadougou, cet article examine les variations de la couverture vaccinale chez les enfants selon la religion dans cinq quartiers de Ouagadougou, au Burkina Faso. II teste l'hypothèse de sélectivité selon laquelle les différences religieuses de santé proviendraient de différences dans la composition socio-économique et démographique des sous-groupes religieux. Même lorsque les caractéristiques socio-économiques et démographiques sont prises en considération, l'association entre religion et couverture vaccinale des enfants demeure. Cela suggère que les disparités religieuses dans les taux de vaccination des enfants ne sont pas uniquement dues à la composition socio-économique et démographique des différents sous-groupes religieux, mais aussi à des différences idéologiques et/ou à des effets de diffusion provenant d'interactions au sein de ces sous-groupes. Cette association avec la religion suggère qu'un accent soit mis sur les approches communautaires impliquant les leaders religieux pour réduire les disparités en santé.

Mots clés : vaccination, religion, enfant, Ouagadougou, Burkina Faso

\section{Introduction}

Emile Durkheim's scientific study of suicide (Durkheim, 1897) is considered the pioneering work on the epidemiological impact of religion, a topic which has become the subject of intense inquiry in the West, before, during and after the epidemiologic transition (Hummer et al., 1999;
Van Poppel et al., 2002). However, in developing countries in general and sub-Saharan Africa in particular, there is a dearth of scientific data on the matter. There is reason to assume that there are meaningful differences between these two contexts. For instance, due to the generally low levels of formal education among sub-Saha-

I. Corresponding author: Abdramane Soura, asoura@issp.bf 
ran African populations, the influence of religion may be greater there. The sway of religion in the region has impacted on several public health campaigns. Reluctance to vaccinate on religious grounds, for example, has been reported in northern Nigeria (Kano, Zamfara, Kuduna) where in 2003 Muslim leaders called on parents to refuse to vaccinate their children against polio, claiming that the vaccine could contain carcinogens, HIV or cause infertility (Jegede, 2007).

Ideological barriers often stand in the way of the Expanded Programme on Immunization (EPI) goal to vaccinate all children, and, consequently, of achieving the fourth Millennium Development Goal to reduce the mortality rate among the under-fives by two thirds between 1990 and 2015 . Thanks to targeted vaccination of child populations, infant and child mortality rates due to many infectious diseases have declined in recent years (Fourn et al., 2009). In order to improve the effectiveness of immunization programs, it is important to measure disparities in childhood immunization rates and understand the causes of these disparities, including those related to religion. In the case of Burkina Faso, a promising attempt of this type of analysis was conducted by the World Bank in 2003, using Demographic and Health Survey data. This work has identified religious differences in child vaccination rates at the national level, particularly with regard to BCG and DPT vaccines. Vaccination rates were higher among children of Christian and Muslim mothers than for those whose mothers belonged to a traditional religion (adjusted relationships). The same religious differences were also observed in antenatal care and place of delivery (Banque Mondiale, 2003). They are likely to be the root causes of religious differences in infant and child mortality rates as observed by Becher et al. (2004) in rural Burkina Faso.

Yet little is known about the influence of religion on children's health in Burkina Faso's urban areas, even if perceptions and prevention of disease have a religious dimension among Burkinabe city dwellers (Ouedraogo, 1994; Gemignani and Wodon, 2012). In fact, very few studies have explored religious health inequalities in African urban areas. This may be because researchers assume that religious differences in health begin to blur and weaken among city dwellers, given their higher educational levels and greater exposure to the West. Using data collected in Ouagadougou, the capital of Burkina Faso, our objective is to examine the religious differences in child vaccination rates in an African urban context. Burkina Faso has long been active in the EPI (in place in the country since 1980) as well as other international initiatives to increase child immunization rates. In 1997, the country joined with its Sahelian neighbors to create the Initiative for Vaccine Independence, aimed at a long-term shift toward regional and country ownership of the EPI and working for the purchase of vaccines and supplies necessary for routine immunization (Ministère de la santé, 2003). Despite these efforts, religion may still affect access to vaccination among children, even in Burkina Faso's large cities.

\section{Theoretical consideration}

Four plausible hypotheses are proposed to explain the influence of religion on health: the selectivity hypothesis (also known as the characteristics hypothesis), the particularized theology hypothesis (otherwise known as the theological doctrine hypothesis), the interaction hypothesis and the minority group status hypothesis. The selectivity hypothesis postulates that religious differences in mortality and health are tied to differences in access to social and human capital (van Poppel el al., 2002). Thus, observed inequalities between religious groups result from underlying socio-economic and demographic differences and not from the religion per se. The Ghanaian sociologist Stephen Gyimah suggests an important distinction between confounding and mediating factors (Gyimah et al., 2006). In Ghana, for example, Christians tend to have higher levels of formal education than Muslims or Animists (Takyi and Addai, 2002). This level of education and its influence on Christian mothers' health care decision making may be considered a mediating factor (Caldwell, 1979; Mosley and Chen, 1984). Variables like the sex of the child, the mother's age and her duration of residence in the city, in contrast, may be considered confounding factors, without obvious links to religion.

The particularized theology hypothesis stems from the work of Durkheim (1897) and considers religion an institution of social control. 
This hypothesis argues that, as a set of values and norms that govern beliefs and behavior, religion has an independent effect on attitudes and behavior. This affects the way people conceptualize and access medical care (Hummer et al., 1999). Studies from Ghana show evidence supporting this idea. Gyimah has indeed discussed how the dominant Christian groups in Ghana (Catholics and mainstream Protestants) promote care-seeking among adherents, while Pentecostal Churches place an emphasis on divine healing (through prayer and fasting) and portray care-seeking in clinics and hospitals as a lack of faith (Gyimah, 2007). Fourn et al. corroborated these findings with a qualitative study in Benin among some leaders and adherents of Protestant sects, who expressed the belief that God gives life and thus the only protection necessary against disease is divine protection (Fourn et al., 2009).

The interaction hypothesis considers religious groups as social institutions through which people learn religious doctrines and are influenced by other members' health behaviour (Zhang, 2008; Yeatman and Trinitapoli, 2008). It may even happen that some members adopt the predominant group behavior without understanding the real reasons, in order to maintain a good relationship with the group. The principle of solidarity within the religious group is emphasized, with members sharing advice, psychological and material support. However, the influence of the group on an individual is strongly dependent on the latter's socio-economic characteristics (Chamie, 1981, cited by Tfaily et al., 2009).

The minority group status hypothesis has been mainly discussed for reproductive behaviors (spacing and limiting births), postulating that minority religious groups adjust their health behaviors to maximize their security and/or social mobility (McQuillan, 2004; Johnson, 1993). This adjustment depends on the social, political and economic context (Tfaily et al., 2009; Morgan et al., 2002). This hypothesis has been already used to explain the reproductive behavior of religious minority groups in Asia Johnson, 1993; Knodel et al., I999; Morgan et al., 2002) and in Northern Ireland (Kennedy, 1973). Since it is not clear in what way belonging to a religious minority group could impact vaccination behaviors, this hypothesis does not fit well in our case.

Our objective is to test the selectivity hypothesis (possible with our data) and explore whether, after accounting for the effects expected by this hypothesis, there is a residual effect of religion on child vaccination rates, attributable to other causes (especially those posited by the particularized theology and interaction hypotheses) without being able to separate their respective effects. We believe that the selectivity hypothesis alone cannot explain the differences in child vaccination rates, given the extent to which religious beliefs shape individuals' perceptions of disease and health behaviors in Burkina Faso (Ouedraogo, 1994; Banque Mondiale, 2003; Gemignani and Wodon , 2012), and given that religious groups are important vehicles of social organization in this country.

\section{Data and methods}

\section{Study site and sample}

This study was conducted in Ouagadougou, the capital city of Burkina Faso, one of the poorest countries in the world (UNDP, 20I3), located in the Sahel region of West Africa. Ouagadougou's population was estimated at $1,475,839$ inhabitants in a 2006 census (Bayala-Ariste, 2009). This represents $10.5 \%$ of the total population of the country and $46.4 \%$ of the country's urban population (Bayala-Ariste, 2009). The main economic sectors in the city are the service sector, trade and crafts. According to the 2006 census data, $57.4 \%$ of Ouagadougou dwellers were Muslims, $34.9 \%$ Catholics, $6.2 \%$ Protestants and less than $1 \%$ were Animists (Bayala-Ariste, 2009). The city is dominated by the Mossi ethnic group, but about sixty small ethnic groups also coexist. Ouagadougou experiences one of the highest child mortality rates among all African capitals, with the under-five mortality estimated at 95 deaths per 1,000 births in 2010 (INSD and ICF international, 20I2).

This analysis uses data collected in the Ouagadougou Health and Demographic Surveillance System (Ouaga HDSS), a research platform for studies and health interventions set up by the Institut Supérieur des Sciences de la Population, University of Ouagadougou in five Ouagadougou neighborhoods (Rossier et al., 20I2). Two of these neighborhoods (Kilwin and Tanghin) are official districts, with full access to 
municipal services. The remaining three neighborhoods (Nonghin, Polesgo and Nioko 2) are unplanned, unofficial peri-urban settlements that lack public services such as electricity and running water. After an initial survey conducted between October 2008 and March 2009, the population of the Ouaga HDSS has been regularly interviewed to register vital events (births, deaths, marriages and migration). As of May 2012, the population tracked by the Ouaga HDSS totaled approximately 83,000 individuals. Over the course of the fourth round of interviews, between July $201 \mathrm{I}$ and May 20I2, fieldworkers recorded information on vaccines received by all children less than 5 years of age, allowing for evaluation of EPI coverage in the HDSS areas. Ethical approval was granted by the Comité d'Ethique pour la Recherche en Santé, Ministry of Health, Burkina Faso (approval number 2010-10, Ethical review board for health research in Burkina Faso).

The dependent variables in this paper (as explained below) require us to limit our analysis to children between 12 and 59 months of age. Two sources were used to obtain this data for 4,985 young children eligible for inclusion. Fieldworkers asked to see children's vaccination booklets, which were produced in $74 \%$ of cases. For the $26 \%$ of cases in which there was no vaccination booklet, fieldworkers relied on mothers' oral reports. Dates of vaccination were copied from the vaccination booklets. If dates of vaccination were not known, the child was not included in the analysis of vaccination by timeframe (explained later), leaving a final sample size of 3,585 children for that analysis.

\section{Variables}

This study examines three dependent variables: I) incomplete vaccination; 2) incomplete vaccination by the WHO's timeframe; and 3) incomplete vaccination by the Burkinabe government's timeframe. According to WHO guidelines, a child is completely vaccinated when s/he has received the BCG vaccine, the measles vac- cine, three doses of the polio vaccine and three doses of the DPT vaccine (against diphtheria, pertussis and tetanus). The WHO's timeframe calls for these vaccinations to be complete by the age of 12 months, while the Burkinabe government's own calendar calls for these vaccines to be complete by the age of 10 months.

The primary independent variable is the religion of the child's parents. Ideally, we would have taken mother's and father's religion into account in the same model. However, we evaluated multicollinearity among all the independent variables by the variance inflation factor and we decided not to include mother's and father's religion in the same model ${ }^{2}$. Their effects have thus been tested separately. We have coded religion into three main categories according to the main religious groups in Ouagadougou: Islam, Catholicism and Protestantism. I4 children have parents professing either a traditional religion or no religion, and because this constitutes such a small proportion of our sample, these children were not included in the analysis.

Based on experiences recorded in other Sahelian settings, we expect to find lower vaccination rates among Muslim families than among Catholic or Protestant families (Jegede, 2007; UNICEF, 2004). In general, Christian families in sub-Saharan Africa tend to be more open to allopathic medicine than their Muslim counterparts. Christianity and allopathic medicine, both propagated in the region by Westerners, share cultural and historical ties that link them together (Akoto, 1990).

A notable difference between Catholics and Protestants is not expected. In each of these groups, there are some scattered churches that promote faith-healing (e.g. Charismatic for Catholics and Pentecostal Churches for Protestants), but their numbers and influence are relatively low in Ouagadougou. In addition, we do not have a variable that allows us to distinguish them from other churches.

Independent variables also include the sex

2. When considering incomplete vaccination as dependent variable, the variance inflation factor (VIF) was estimated at about 4.9 for father's and mother's religions while it was around I for other independent variables. When considering incomplete vaccination before 10 months or 12 months of age as dependent variable, the VIF was estimated at about 5.2 for father's and mother's religions while it was around I for other independent variables. According to Craney and Surles (2002), there is no formal criteria for deciding when the VIF is too large but a value around 5 is generally considered strong enough to introduce biases in the models. By choosing to put separately father's and mother's religions in the models, their variance inflation factors fall to about I. 
and age of the child, the age of the parents at the child's birth, their duration of residence in the city, their educational level, their standard of living, and their ethnic group. Among the control variables, we distinguish between official and unofficial neighborhoods of residence, as well as the presence of a health center in the neighborhood. The impact of these factors on children's health is the subject of a wide body of literature (Baya, 1998; Soura, 2009). It would perhaps have been interesting to take into account the experience of each woman in terms of utilization of maternal and child health services by creating an indicator based on the use of prenatal care and place of delivery. But since the sample is not composed solely of children born within the study zone, we do not have complete information on prenatal and birth conditions for each child. Furthermore, the large majority
(94\%) of women in our population seek prenatal care and give birth in health centers; so these independent variables would offer little variability.

A lack of data on direct income led us to create a proxy variable for standard of living that takes into account both the presence of a refrigerator and a television in the household, as well as the most expensive mode of transport available in that household (a household with both a motor scooter and a car, for example, is classified as a car-owning household). The coefficient attached to each good is derived from a Principal Components Analysis (PCA). Based on the scores of the first factor of the PCA (which accounts for $50.4 \%$ of the variance), three categories of household were delineated: the poorest, the middle and the wealthiest (Table I).

Table I Household characteristics and goods in possession by standard of living

\begin{tabular}{llll}
\hline Household characteristics and goods in possession & \multicolumn{2}{l}{ Living Standard } & \\
\cline { 2 - 4 } & Low & Middle & High \\
\cline { 2 - 4 } & Score : $-0,67$ & Score : 0, 13 - I,84 & Score : 1,92 - 2,64 \\
\hline Refrigerator & $0 \%$ & $1.6 \%$ & $82.3 \%$ \\
Television & $0 \%$ & $47.9 \%$ & $99.1 \%$ \\
Mode of transportation & & & \\
On foot or by bicycle & $100 \%$ & $7.5 \%$ & $0 \%$ \\
Motor-Scooter & $0 \%$ & $91.4 \%$ & $46.8 \%$ \\
Car & $0 \%$ & $1.1 \%$ & $53.2 \%$ \\
\hline
\end{tabular}

\section{Statistical methods}

Since the dependent variables are all binary, a logistic regression is used to test the relationships $^{3}$. This regression consists of modeling the logarithm of the odds ratio as a linear function of explanatory variables. The exponential of each coefficient indicates the odds ratio between the category and the corresponding reference category for each categorical variable, when all else is equal.

In our multivariate analysis, the effects of the child's mother's and father's religion are tested separately, and three separate models are built for each dependent variable. The first model tests the gross effect of religion. The second tests the mediating effect of education. The third model tests the effect of religion independently of all the control variables. In the first model, the age of the child is controlled when analyzing full vaccination regardless of age limit.

\section{Results}

\section{Sample description}

Table 2 shows the distribution of the sample by independent variables. Most parents fall into the intermediary age group (20-34 years old), have no formal education, and have lived in Ouagadougou for more than 5 years. Most parents are also from the Mossi ethnic group and are Muslim. The distribution of standards of living shows that most people fall into our definition of mid-

3. Although we have considered all children between I and 5 years, the data indicate very few repeated observations per mother: $92.3 \%$ of mothers had only one birth in the sample and the average number of children per mother in the sample was only I.08. A high number of multiple observations per mother would have led us to use a multilevel analysis. 
dle class.

Table 2 Distribution of the sample (\%) by parents' religion and control variable

\begin{tabular}{|c|c|c|c|c|c|c|c|c|}
\hline Variables & Mother' & Religion & & & Father's & ligion & & \\
\hline & Muslim & Catholic & Protestant & Total & Muslim & Catholic & Protestant & Total \\
\hline Age of the child, in months & & & & & & & & \\
\hline $12-17$ months & 20.9 & 22.3 & 22.2 & 21.3 & 20.6 & 22.7 & 23.3 & 21.3 \\
\hline $18-23$ months & 19.0 & 20.3 & 23.7 & 19.6 & 19.1 & 20.3 & 22.6 & 19.6 \\
\hline $24-59$ months & 60.1 & 57.4 & 54.2 & 59.0 & 60.2 & 57.1 & 54.1 & 59.0 \\
\hline Sex of the child & & & & & & & & \\
\hline Male & 50.1 & 48.1 & 46.8 & 49.4 & 49.9 & 48.7 & 46.6 & 49.4 \\
\hline Female & 49.9 & 51.9 & 53.2 & 50.6 & 50.1 & 51.3 & 53.4 & 50.6 \\
\hline Age of parent at child's birth & & ***** & & & & & & \\
\hline Under 20 years old & 16.0 & 10.2 & 8.6 & 14.1 & - & - & - & - \\
\hline $\begin{array}{l}\text { Between } 20 \text { and } 34 \text { years } \\
\text { old }\end{array}$ & 76.8 & 81.4 & 82.5 & 78.3 & 58.4 & 59.9 & 60.0 & 58.9 \\
\hline 35 years old and greater & 7.2 & 8.4 & 8.9 & 7.6 & 41.6 & 40.1 & 40.0 & $4 I .1$ \\
\hline $\begin{array}{l}\text { Length of time lived in } \\
\text { Ouagadougou }\end{array}$ & & *** & & & & ***** & & \\
\hline Fewer than 5 years & 14.3 & 10.4 & 13.9 & 13.3 & 6.2 & 5.2 & 4.9 & 5.8 \\
\hline 5 years or greater & 60.0 & 61.3 & 66.2 & 60.7 & 74.9 & 69.1 & 80.3 & 73.7 \\
\hline Born in Ouaga & 25.8 & 28.3 & 20.0 & 26.0 & 19.0 & 25.8 & 14.8 & 20.4 \\
\hline Level of Education & & ***** & & & & ***** & & \\
\hline None & 61.3 & 44.1 & 48.0 & 56.2 & 54.4 & 31.8 & 36.7 & 47.5 \\
\hline Primary & 23.4 & 29.2 & 26.2 & 25.0 & 27.4 & 33.9 & 27.5 & 29.1 \\
\hline Secondary and greater & 15.3 & 26.7 & 25.9 & 18.8 & 18.2 & 34.3 & 35.7 & 23.4 \\
\hline Ethnic Background & & & & & & * & & \\
\hline Mossi & 91.1 & 91.2 & 88.6 & 91.0 & 92.2 & 91.9 & 87.9 & 91.8 \\
\hline Other & 8.9 & 8.8 & 11.4 & 9.0 & 7.8 & 8.1 & 12.1 & 8.2 \\
\hline Standard of Living & & **⿻丷木大 & & & & ***** & & \\
\hline Low & 33.1 & 32.2 & 35.4 & 33.0 & 33.3 & 31.6 & 35.4 & 33.0 \\
\hline Middle & 59.7 & 57.9 & 56.6 & 59.1 & 59.7 & 57.9 & 57.4 & 59.1 \\
\hline High & 7.2 & 9.9 & 8.0 & 7.9 & 7.0 & 10.5 & 7.2 & 7.9 \\
\hline Type of Neighborhood & & **⿻丷木大 & & & & **⿻丷木 & & \\
\hline Official & 33.8 & 33.2 & 26.2 & 33.2 & 33.4 & 34.5 & 24.6 & 33.2 \\
\hline Unofficial & 66.2 & 66.8 & 73.9 & 66.8 & 66.6 & 65.5 & 75.4 & 66.8 \\
\hline Presence of a Health Center & & * & & & & **⿻丷木 & & \\
\hline No & 56.2 & 56.9 & 63.1 & 56.8 & 56.7 & 55.2 & 65.3 & 56.8 \\
\hline Yes & 43.8 & 43.1 & 36.9 & 43.2 & 43.3 & 44.8 & 34.8 & 43.2 \\
\hline Sample Size & 3907 & 1498 & 380 & 4985 & 3406 & 1274 & 305 & 4985 \\
\hline Percentage & 67.5 & 25.9 & 6.6 & 100.0 & 68.3 & 25.6 & 6.1 & 100.0 \\
\hline
\end{tabular}

Chi-Square Test (relation between column variable and row variable): ${ }^{*} \mathrm{p}<0.1$; ${ }^{* *} \mathrm{p}<0.05 ;{ }^{* * *} \mathrm{p}<0.00$ I

This table also shows that different religions are associated with different socio-economic and demographic characteristics. Most notably, we see that Muslim families are disadvantaged in terms of parents' level of education. The majority of Muslim children in the sample have parents with no formal education (Table 2).
Descriptive analysis

Figure I shows that the vaccination coverage rate varies by religion. Children of Muslim parents are less likely to be fully vaccinated. For example, among children in Muslim families, $34 \%$ were not fully vaccinated by the age of 10 months, compared to $25 \%$ among Catholics and Protestants. Between the two Christian denominations, the differences are small, as 
expected.

Figure 1: Percentage of children incompletely vaccinated by timeframe and parents' religion

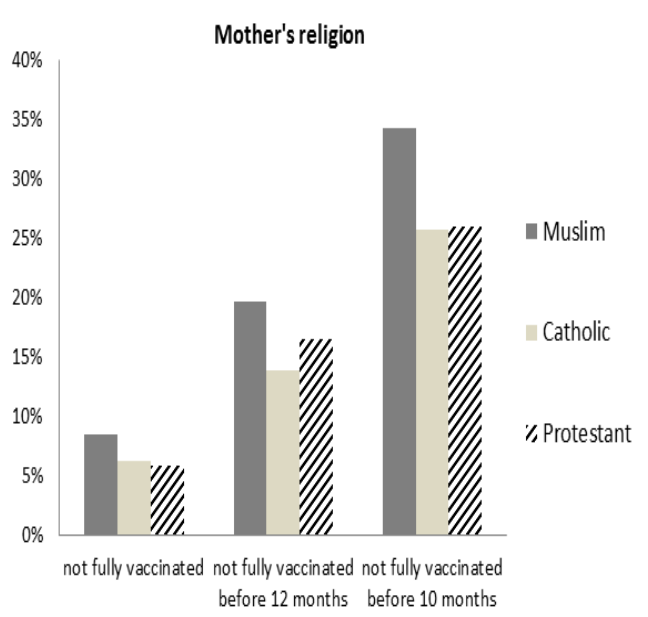

The unadjusted odds ratios (Table 3 ) show that children of a Catholic mother or father have a lower risk of not receiving all of the routine vaccinations than children of Muslim parents (odds ratio $=0.72$ for children of Catholic mothers). When it comes to incomplete vaccination by 12 months or 10 months of age, the odds ratio is

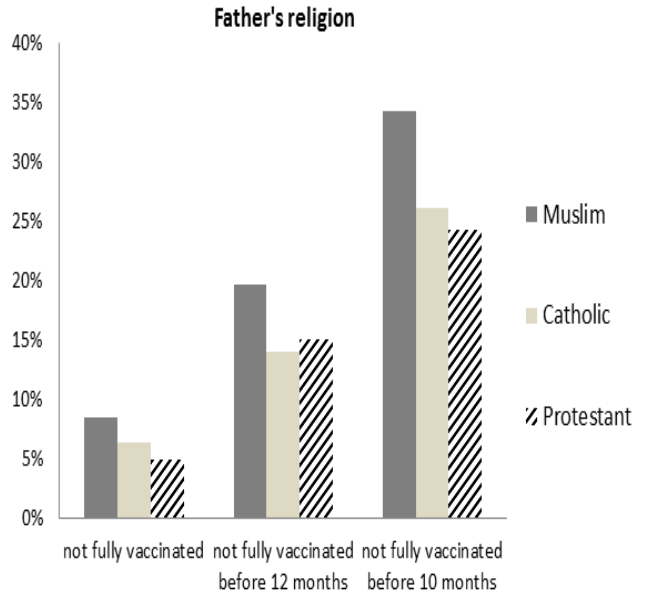

0.66. Children with Protestant parents also have a lower risk of being incompletely vaccinated than those with Muslim parents. The odds ratio for not being fully vaccinated before 12 months in this group is not statistically significant when considering the mother's religion, but it nevertheless skews in the expected direction.

Table 3 Percentage of children incompletely vaccinated and odds ratios by timeframe and independent variable

\begin{tabular}{|c|c|c|c|c|c|c|c|c|c|c|c|c|}
\hline \multirow[t]{3}{*}{ Variables } & \multicolumn{6}{|c|}{ Model with mother's characteristics } & \multicolumn{6}{|c|}{ Model with father's characteristics } \\
\hline & \multicolumn{2}{|c|}{$\begin{array}{l}\text { Incomplete } \\
\text { vaccination }\end{array}$} & \multicolumn{2}{|c|}{$\begin{array}{c}\text { Incomplete } \\
\text { vaccination by } 12 \\
\text { months }\end{array}$} & \multicolumn{2}{|c|}{$\begin{array}{l}\text { Incomplete } \\
\text { vaccination by } \\
10 \text { months }\end{array}$} & \multicolumn{2}{|c|}{$\begin{array}{l}\text { Incomplete } \\
\text { vaccination }\end{array}$} & \multicolumn{2}{|c|}{$\begin{array}{l}\text { Incomplete } \\
\text { vaccination by } \\
12 \text { months }\end{array}$} & \multicolumn{2}{|c|}{$\begin{array}{c}\text { Incomplete } \\
\text { vaccination by } \\
10 \text { months }\end{array}$} \\
\hline & $\%$ & OR & $\%$ & OR & $\%$ & OR & $\%$ & OR & $\%$ & OR & $\%$ & OR \\
\hline \multicolumn{13}{|l|}{ Age of child in months } \\
\hline I2-17 Months & 12.8 & 1 & & - & & - & 12.8 & I & & - & & - \\
\hline 18-23 Months & 6.8 & $0.50 * * *$ & & - & & - & 6.8 & $0.50 * * *$ & & - & & - \\
\hline $24-59$ Months & 6.3 & $0.46 * * *$ & & - & & - & 6.3 & $0.46 * * *$ & & - & & - \\
\hline \multicolumn{13}{|l|}{ Religion } \\
\hline Muslim & 8.5 & I & 19.7 & I & 34.3 & 1 & 8.5 & I & 19.7 & I & 34.3 & I \\
\hline Catholic & 6.3 & $0.72 * *$ & 13.9 & $0.66 * * *$ & 25.7 & $0.66 * * *$ & 6.4 & $0.74 * *$ & 14.1 & $0.67 * * *$ & 26.1 & $0.68 * * *$ \\
\hline Protestant & 5.8 & $0.67 *$ & 16.5 & 0.80 & 25.9 & $0.67 * *$ & 4.9 & $0.55^{* * *}$ & 15.1 & $0.73 *$ & 24.2 & $0.61 * *$ \\
\hline \multicolumn{13}{|l|}{ Sex of the child } \\
\hline Male & 7.2 & I & 17.4 & I & 31.4 & 1 & 7.2 & I & 17.4 & I & 31.4 & I \\
\hline Female & 8.3 & 1.17 & 18.5 & 1.08 & 31.6 & 1.01 & 8.3 & 1.17 & 18.5 & 1.08 & 31.6 & 1.01 \\
\hline \multicolumn{13}{|l|}{$\begin{array}{l}\text { Age of parent at child's } \\
\text { birth }\end{array}$} \\
\hline Under 20 years old & 8.6 & 1.14 & 20.0 & 1.17 & 32.7 & 1.08 & - & - & - & - & - & - \\
\hline 20-34 years old & 7.6 & I & 17.6 & 1 & 31.1 & 1 & 7 & I & 16.7 & I & 30 & I \\
\hline $\begin{array}{l}35 \text { years old and } \\
\text { greater }\end{array}$ & 8.7 & 1.16 & 18.3 & 1.05 & 33.2 & 1.10 & 8.9 & $1.30 * *$ & 19.9 & $1.24 * *$ & 33.6 & $1.18 * *$ \\
\hline \multicolumn{13}{|l|}{$\begin{array}{l}\text { Length of time lived in } \\
\text { Ouagadougou }\end{array}$} \\
\hline Fewer than 5 years & 10.0 & I & 20.2 & I & 35.1 & 1 & 8.6 & I & 21.3 & I & 36 & I \\
\hline
\end{tabular}




\begin{tabular}{|c|c|c|c|c|c|c|c|c|c|c|c|c|}
\hline 5 years and greater & 7.8 & $0.76 *$ & 17.7 & 0.85 & 32.3 & 0.88 & 8.1 & 0.94 & 18.4 & 0.83 & 31.7 & 0.82 \\
\hline Born in Ouaga & 6.7 & $0.65 * *$ & 17.3 & 0.83 & 27.4 & $0.70 * *$ & 6.3 & 0.71 & 15.4 & $0.67 * *$ & 29.3 & $0.73 *$ \\
\hline \multicolumn{13}{|l|}{ Level of education } \\
\hline None & 9.2 & I & 20.8 & I & 36.9 & 1 & 9.5 & 1 & 20.9 & I & 37.1 & I \\
\hline Primary & 7.2 & $0.77^{* *}$ & 16.6 & $0.76 * *$ & 28.2 & $0.67 * * *$ & 7.4 & $0.76 * *$ & 17.7 & $0.8 I^{* *}$ & 30 & $0.73 * * *$ \\
\hline $\begin{array}{l}\text { Secondary and } \\
\text { greater }\end{array}$ & 4.4 & $0.45 * * *$ & 10.7 & $0.46 * * *$ & 18.9 & $0.40 * * *$ & 4.8 & $0.48 * * *$ & 12 & $0.51 * * *$ & 21.3 & $0.46 * * *$ \\
\hline \multicolumn{13}{|l|}{ Ethnic background } \\
\hline Mossi & 7.8 & 1 & 17.9 & 1 & 31.8 & I & 7.8 & 1 & 17.7 & I & 31.6 & 1 \\
\hline Other & 7.8 & 1.00 & 18.9 & 1.07 & 28.1 & 0.84 & 8.1 & 1.05 & 20.8 & 1.22 & 30.4 & 0.95 \\
\hline \multicolumn{13}{|l|}{ Standard of living } \\
\hline Low & 9.7 & 1 & 20.6 & I & 36.4 & I & 9.7 & 1 & 19.7 & I & 36.4 & I \\
\hline Middle & 7.3 & $0.73^{* *}$ & 17.2 & $0.80 * *$ & 30.1 & $0.75^{* * * *}$ & 7.3 & $0.73 * *$ & 13.9 & $0.80 * *$ & 30.1 & $0.75^{* * *}$ \\
\hline High & 3.8 & $0.37 * * *$ & 9.9 & $0.42 * * *$ & 16.6 & $0.35 * * *$ & 3.8 & $0.37^{* * * *}$ & 16.5 & $0.42 * * * *$ & 16.6 & $0.35 * * *$ \\
\hline \multicolumn{13}{|l|}{ Type of neighborhood } \\
\hline Official & 6.0 & 1 & 15.7 & 1 & 27.2 & 1 & 6 & 1 & 15.7 & 1 & 27.2 & 1 \\
\hline Unofficial & 8.7 & $1.49 * *$ & 18.9 & $1.25 * *$ & 33.2 & $1.33 * * *$ & 8.7 & $1.49 * *$ & 18.9 & $1.25 * *$ & 33.2 & $1.33 * * *$ \\
\hline \multicolumn{13}{|l|}{$\begin{array}{l}\text { Presence of a health } \\
\text { center }\end{array}$} \\
\hline No & 9.0 & 1 & 19.1 & 1 & 33.2 & I & 9 & 1 & 19.1 & I & 33.2 & I \\
\hline Yes & 6.1 & $0.66 * * *$ & 16.2 & $0.82 * *$ & 28.5 & $0.80 * *$ & 6.1 & $0.66 * * *$ & 16.2 & $0.82 * *$ & 28.5 & $0.80 * *$ \\
\hline Sample size & 4985 & & 3585 & & 3585 & & 4985 & & 3585 & & 3585 & \\
\hline
\end{tabular}

Among the control variables, educational level and standard of living have the strongest relationships with care-seeking behavior (Table 3), each showing a positive relationship with vaccination rates. The proportion of children who are not fully vaccinated by the age of 10 months, which is $37 \%$ when the child's mother has no education, falls to $19 \%$ when she has a secondary education or higher. This proportion also falls from $21 \%$ to $11 \%$ within the 12 month WHO timeframe, numbers that remain relatively stable if the father's level of education is taken into account. Similarly, standard of living is also significantly related to all three measures of child vaccination. Unsurprisingly, children from poor families are disadvantaged compared to children from wealthier families. For example, $36 \%$ among poor children have not received all the routine vaccinations by 10 months, compared to $17 \%$ among wealthier families.

The child's sex, the mother's age and the parents' ethnicity are all factors that seem to have no important relationship with child vaccination. Other factors (type of neighborhood, presence of a health center in the neighborhood) may have some relationship with child vaccination rates, but these relationships are tenuous.

\section{Multivariate analysis}

Tables 4 and 5 show the results of the multivariate analysis. They show a significant relationship between child vaccination rates and parents' religious affiliation (be it the mother's or the father's), for all three measures of child vaccination. When compared to children in Muslim families, those in Catholic families have less risk of being incompletely vaccinated when all else is equal (odds ratio $\sim 0.7 \mathrm{I}$, model MI.3, Tables 4 \& 5). When we look at mothers' religion only, the odds of a Catholic mother not vaccinating her child before 12 months or 10 months of age is almost $30 \%$ lower than those of a Muslim mother (Models M2.3 \& M3.3, Table 4). Looking at the fathers' religion, these ratios are estimated at 0.73 and 0.75 respectively (Models M2.3 \& M3.3, Table 5). 
Table 4 Odds ratios for incomplete vaccination (model with mothers' characteristics)

\begin{tabular}{|c|c|c|c|c|c|c|c|c|c|}
\hline \multirow[t]{3}{*}{ Variables } & \multicolumn{9}{|c|}{ Model with mothers' characteristics } \\
\hline & \multicolumn{3}{|c|}{ Incomplete vaccination } & \multicolumn{3}{|c|}{$\begin{array}{l}\text { Incomplete vaccination } \\
\text { before } 12 \text { months }\end{array}$} & \multicolumn{3}{|c|}{$\begin{array}{l}\text { Incomplete vaccination before } \\
10 \text { months }\end{array}$} \\
\hline & MI.I & MI.2 & MI.3 & M2.I & M2.2 & M2.3 & M3.I & M3.2 & M3.3 \\
\hline \multicolumn{10}{|l|}{ Age of child in months } \\
\hline $12-17$ Months & 1 & 1 & & - & - & - & - & - & - \\
\hline I8-23 Months & $0.50 * * *$ & $0.49 * * *$ & $0.49 * * *$ & - & - & - & - & - & - \\
\hline $24-59$ Months & $0.45^{* * *}$ & $0.45 * * *$ & $0.46 * * *$ & - & - & - & - & - & - \\
\hline \multicolumn{10}{|l|}{ Religion } \\
\hline Muslim & 1 & 1 & 1 & 1 & 1 & 1 & 1 & 1 & 1 \\
\hline Catholic & $0.7 I^{* *}$ & $0.78^{*}$ & $0.77^{* * *}$ & $0.66^{* * * *}$ & $0.7 I^{* *}$ & $0.7 I^{* *}$ & $0.66^{* * * *}$ & $0.72 * *$ & $0.72 * * *$ \\
\hline Protestant & $0.66^{*}$ & 0.71 & 0.69 & 0.80 & 0.86 & 0.87 & $0.67 * *$ & $0.73 * *$ & $0.72 * *$ \\
\hline \multicolumn{10}{|l|}{ Level of education } \\
\hline None & & I & 1 & & 1 & 1 & & 1 & 1 \\
\hline Primary & & $0.79 *$ & 0.84 & & $0.78 * *$ & $0.78 * *$ & & $0.69 * * *$ & $0.73 * * *$ \\
\hline Secondary and greater & & $0.46 * * *$ & $0.54 * * * *$ & & $0.48 * * *$ & 0.49**** & & $0.42 * * * *$ & $0.48 * * *$ \\
\hline \multicolumn{10}{|l|}{ Sex of the child } \\
\hline Male & & & 1 & & & 1 & & & 1 \\
\hline Female & & & 1.17 & & & 1.08 & & & 0.99 \\
\hline \multicolumn{10}{|l|}{ Age of parent at child's birth } \\
\hline Under 20 years old & & & 1.09 & & & 1.12 & & & 1.01 \\
\hline 20-34 years old & & & 1 & & & 1 & & & 1 \\
\hline 35 years old and greater & & & 1.14 & & & 1.02 & & & 1.07 \\
\hline \multicolumn{10}{|l|}{$\begin{array}{l}\text { Length of time lived in } \\
\text { Ouagadougou }\end{array}$} \\
\hline Fewer than 5 years & & & 1 & & & 1 & & & 1 \\
\hline 5 years and greater & & & 0.84 & & & 0.96 & & & 0.98 \\
\hline Born in Ouaga & & & 0.92 & & & 1.16 & & & 0.98 \\
\hline \multicolumn{10}{|l|}{ Ethnic background } \\
\hline Mossi & & & 1 & & & 1 & & & I \\
\hline Other & & & 1.17 & & & 1.13 & & & 0.96 \\
\hline \multicolumn{10}{|l|}{ Standard of living } \\
\hline Low & & & I & & & 1 & & & 1 \\
\hline Middle & & & $0.80 *$ & & & $0.85 *$ & & & $0.83 * *$ \\
\hline High & & & $0.55^{*}$ & & & $0.54 * *$ & & & $0.48 * * *$ \\
\hline \multicolumn{10}{|l|}{ Type of neighborhood } \\
\hline Official & & & 1 & & & I & & & 1 \\
\hline Unofficial & & & 0.91 & & & 0.91 & & & 0.98 \\
\hline \multicolumn{10}{|l|}{ Presence of a heath center } \\
\hline No & & & 1 & & & 1 & & & I \\
\hline Yes & & & 0.74 & & & 0.87 & & & 0.95 \\
\hline Log likelihood & - & 1325.60 & $-\overline{1316.58}$ & 1679.75 & $-\overline{1663.7 \mid}$ & -1656.86 & 2219.78 & 2184.17 & -2174.88 \\
\hline LR chi-square & $51.56 * * *$ & $75.06 * * *$ & $93.09 * * *$ & $16.45^{* * * *}$ & $48.52 * * *$ & $62.23 * * *$ & $27.23 * * *$ & $98.46 * * *$ & II $7.03 * * *$ \\
\hline
\end{tabular}

NB: *p $<0.1 ;{ }^{* *} \mathrm{p}<0.05 ;{ }^{* * *} \mathrm{p}<0.00$ I 
Table 5 Odds ratios for incomplete vaccination (model with fathers' characteristics)

\begin{tabular}{|c|c|c|c|c|c|c|c|c|c|}
\hline \multirow[t]{3}{*}{ Variables } & \multicolumn{9}{|c|}{ Model with fathers' characteristics } \\
\hline & \multicolumn{3}{|c|}{ Incomplete vaccination } & \multicolumn{3}{|c|}{$\begin{array}{l}\text { Incomplete vaccination } \\
\text { before } 12 \text { months }\end{array}$} & \multicolumn{3}{|c|}{$\begin{array}{l}\text { Incomplete vaccination before } \\
10 \text { months }\end{array}$} \\
\hline & MI.I & MI.2 & MI.3 & M2.I & M2.2 & M2.3 & M3.I & $M 3.2$ & M3.3 \\
\hline \multicolumn{10}{|l|}{ Age of child in months } \\
\hline I2-17 Months & 1 & 1 & 1 & - & - & - & - & - & - \\
\hline I8-23 Months & $0.50 * * *$ & $0.50 * * *$ & $0.50 * * *$ & - & - & - & - & - & - \\
\hline $24-59$ Months & $0.45^{* * * *}$ & $0.45 * * * *$ & $0.46 * * *$ & - & - & - & - & - & - \\
\hline \multicolumn{10}{|l|}{ Religion } \\
\hline Muslim & 1 & 1 & 1 & 1 & $\mathrm{I}$ & 1 & I & 1 & I \\
\hline Catholic & $0.72^{* * *}$ & $0.8 I^{*}$ & $0.79 *$ & $0.67 * * *$ & $0.73 * *$ & $0.73 * *$ & $0.68^{* * * *}$ & $0.76^{* * *}$ & $0.75 * *$ \\
\hline Protestant & $0.54 * *$ & $0.60 *$ & $0.56 * *$ & $0.73^{*}$ & 0.80 & 0.77 & $0.6 I^{* *}$ & $0.69 * *$ & $0.67 * *$ \\
\hline \multicolumn{10}{|l|}{ Level of education } \\
\hline None & & 1 & 1 & & $\mathrm{I}$ & 1 & & 1 & I \\
\hline Primary & & $0.77^{* * *}$ & 0.83 & & $0.84 *$ & 0.90 & & $0.76 * *$ & $0.78 * *$ \\
\hline Secondary and greater & & $0.50 * * *$ & $0.6 I^{* *}$ & & $0.55^{* * * *}$ & $0.62 * * *$ & & $0.49 * * * *$ & $0.56 * * *$ \\
\hline \multicolumn{10}{|l|}{ Sex of the child } \\
\hline Male & & & 1 & & & 1 & & & I \\
\hline Female & & & 1.17 & & & 1.07 & & & 1.0 \\
\hline \multicolumn{10}{|l|}{ Age of parent at child's birth } \\
\hline \multicolumn{10}{|l|}{ Under 20 years old } \\
\hline 20-34 years old & & & 1 & & & 1 & & & 1 \\
\hline 35 years old and greater & & & $\mathrm{I} .2 \mathrm{I}^{*}$ & & & I.20* & & & $1.13^{*}$ \\
\hline \multicolumn{10}{|l|}{$\begin{array}{l}\text { Length of time lived in } \\
\text { Ouagadougou }\end{array}$} \\
\hline Fewer than 5 years & & & 1 & & & 1 & & & I \\
\hline 5 years and greater & & & 0.96 & & & 0.86 & & & 0.97 \\
\hline Born in Ouaga & & & 0.90 & & & 0.79 & & & 0.90 \\
\hline \multicolumn{10}{|l|}{ Ethnic background } \\
\hline Mossi & & & 1 & & & 1 & & & 1 \\
\hline Other & & & 1.24 & & & $1.34 *$ & & & $\mathrm{I} .08$ \\
\hline \multicolumn{10}{|l|}{ Standard of living } \\
\hline Low & & & 1 & & & 1 & & & 1 \\
\hline Middle & & & $0.80 *$ & & & 0.87 & & & $0.82 * *$ \\
\hline High & & & $0.52 * *$ & & & $0.5 I^{* *}$ & & & $0.44 * * *$ \\
\hline \multicolumn{10}{|l|}{ Type of neighborhood } \\
\hline Official & & & 1 & & & 1 & & & 1 \\
\hline Unofficial & & & 0.91 & & & 0.92 & & & 0.98 \\
\hline \multicolumn{10}{|l|}{ Presence of a health center } \\
\hline No & & & 1 & & & 1 & & & 1 \\
\hline Yes & & & 0.75 & & & 0.90 & & & 0.94 \\
\hline Log likelihood & - & - & - & - & - & - & $-\overline{2219.61}$ & $-\overline{2192.81}$ & $-2179.9 \mid$ \\
\hline LR chi-square & $53.81 * * *$ & $75.40 * * *$ & $95,63 * * *$ & $16.35 * * *$ & $4 I .11 * * *$ & $60.32 * * *$ & $27.57 * * *$ & $81.17 * * *$ & $106.97 * * *$ \\
\hline
\end{tabular}

NB: $* \mathrm{p}<0.1 ; * * \mathrm{p}<0.05 ; * * * \mathrm{p}<0.001$

Our results also show that the differences in vaccination rates are stark between children of Protestant and Muslim fathers, especially when looking at full vaccination overall or full vaccination by the age of 10 months (MI.3 \& M3.3, Table 5). Protestant fathers are more likely to 
vaccinate their children. Only vaccination by 12 months of age does not show a significant difference between children of Protestant and Muslim fathers (M2.3, Table 5). It does not show a significant difference either when the comparison is made with the religion of the mother (M2.3, Table 4). This remains the case when children are compared in terms of full vaccination without a timeframe (MI.3, Table 4).

Overall, religious differences in child vaccination rates persist, even after taking into account parents' level of education. These differences sometimes weaken or disappear when comparing Protestants and Muslims (M.I.I \& MI.2, Table 4; M2.I \& M2.2, Table 5).

Among the control variables, parents' educational level and standard of living are the most strongly related to child vaccination, a phenomenon that is observed in many studies on child health in Africa. When all else is equal, the higher the mother's educational level, the lower the likelihood that her child will be incompletely vaccinated, whether by 12 months or 10 months (Table 4). This relationship, however, is not apparent among uneducated mothers and mothers with only a primary education when it comes to incomplete vaccination without a timeframe (Table 4, MI.3). Also, children with fathers who have a primary education have the same chance of being vaccinated by 12 months as do those whose fathers have no formal education (Table 5, Model M2.3). With standard of living, it appears that the odds ratio of incomplete vaccination varies between 0.44 and 0.55 when the wealthiest families are compared to the poorest (Tables $4 \& 5$ ).

At the $10 \%$ error threshold, two other variables are significant: father's age and his ethnic group (Table 5). Older fathers (those older than 35) tend to vaccinate their children less than other age groups do, when all else is equal. The effect of ethnic group is apparent only on vaccination by 12 months, for which the children of Mossi fathers seem to be at an advantage. The apparent effects of other variables (duration in Ouagadougou, presence of a health center nearby, type of neighborhood) disappear once socio-economic differences are taken into account.

\section{Discussion}

Though the reluctance of some religious groups to vaccinate their children in sub-Saharan Africa has been the issue of much discussion (Jegede, 2007; Fourn et al., 2009; UNICEF, 2004), there has been very little objective scientific measurement of the religious differences in child vaccination rates. Our bivariate analysis showed differences in child vaccination rates based on parents' religion in the Ouagadougou Health and Demographic Surveillance area. Compared to the children of Muslims (Muslim mother or father), children of Catholics are more likely to receive all of their routine vaccines, be it by the WHO's 12 month timeframe or the Burkinabe government's 10 month timeframe. There are no significant differences between Protestants and Catholics, results which are consistent with our expectations. This religious disparity in vaccination rates might be attributable to the particular socio-economic and demographic makeup of the different religions. For instance, we have seen that a majority of Muslim parents have no education, lending credence to the idea that education among Muslims is generally lower than among Christians, in this setting and others (Takyi and Addai, 2002).

However, the control variables could not account for the effect of religion. The vaccination advantage of the children of Catholic parents persists across all models, though it weakens slightly when the level of parents' education is taken into account. The importance of education as a mediating factor is more apparent when Protestant mothers are compared to Muslim mothers, especially in terms of complete immunization, regardless of age and before the 12 months of age. For both dependent variables, the gap between Muslim and Protestant families loses significance when the mother's level of education is taken into account, signifying that this difference represents a composition effect. When the criteria for full vaccination become stricter (by 10 months), differences in child vaccination rates between Protestant and Muslim mothers become more apparent. The father's religion appears to have a more consistent relationship with child vaccination, with the children of Protestant fathers more likely to be vaccinated than those of Muslim fathers. 
The vaccination disadvantage that the children of Muslim parents have may be related to false ideas about the dangers of vaccines, which are more widely circulated in Muslim communities (UNICEF, 2004). Informal interviews conducted in our study area with one religious leader and three women for every religious affiliation (Muslim, Catholic, Protestant) show support for this idea. Fears of infertility due to vaccination were raised by some Muslim informants, but not by Catholic or Protestant informants.

These religious differences suggest that a greater emphasis should be put on communitybased approaches to reducing health disparities in Burkina Faso. For the particular case of child vaccination, religious communities and informal prayer groups could be used to help educate their members about the importance of vaccination. The social influence that religious groups exert is undeniable, and harnessing their power can help counteract the rumors and help support adherents' decisions to vaccinate their children. This could lead to a greater coverage of vaccination, a result already demonstrated by UNICEF (2004) in several developing countries. In Sierra Leone, for example, a country that's $60 \%$ Muslim, facing poor vaccination coverage in the mid-1980s, UNICEF worked to create an Islamic Action Group that was instrumental in subsequent community mobilization efforts (UNICEF, 2004). Religious leaders spoke highly of vaccination in mosques and a federation of 96 Muslim women's groups helped prepare mass vaccination campaigns in collaboration with health workers. The result of these efforts was impressive, with the vaccination rate for children under I year of age skyrocketing from $6 \%$ in 1986 to $75 \%$ in 1990 (UNICEF, 2004). Another prime example of the power of religious communities to promote healthy behaviors comes from the Indian state of Bihar, where Imams were recruited to help promote the polio vaccine (UNICEF, 2004). They included the benefits of the vaccine in their sermons and informal discussions with their faithful, and endorsing a brochure written in the local languages (Hindu and Urdu) that called on Muslims to vaccinate their children. This strategy massively increased the participation of Muslim families in polio vaccination campaigns.

The observed inequalities based on certain control variables (parents' educational level and standard of living) reinforce the need for multidimensional efforts to improve community health. Health disparities have multiple causes, and their alleviation cannot come from the health sector alone (Turrell, 2002). Rather multisectoral efforts must be undertaken to address their social and economic root causes. Health workers and researchers must become advocates to inform decision makers about the realities on the ground, and the impact of policy decisions on marginalized groups (Turrell, 2002).

This study has some limitations. Due to the cross-sectional nature of the data used, causal inference from the observed relations must be careful and judicious. Another limitation is the possible sample selection due to the fact that only data on surviving children were collected. Children who died were probably those who were not immunized. A lack of information on religious beliefs and participation in religious activities requires us to limit our measures to religious affiliation as the proxy for religion in this study. A measure of religiosity would probably better capture the impact of religion on health behavior. Moreover, given the nature of the data used, the study could not test all the theoretical hypotheses that explain the relationship between religion and health. Only the selectivity hypothesis was tested and the results showed that it cannot alone explain the religious differences in children's vaccination rates in Ouagadougou. Finally, birth order was not included in this analysis due to a lack of data on the subject. Care given by parents to a child can often depend on birth order; the lack of inclusion of this information presents a limitation.

\section{Conclusion}

Like other countries that have adopted the EPI, Burkina Faso has been working to achieve universal child vaccination (Ministère de la santé, 2003). Mass vaccination campaigns have complemented the routine immunizations provided in clinics and health centers. Vaccines, like the oral polio vaccine, have been the subject of intense door-to-door outreach campaigns, organized as part of the Global Polio Eradication Initiative. Vaccines that require a needle for administration have also been the subject of 
large-scale campaigns, both clinic-based and with mobile outreach teams going into neighborhoods. All of these strategies have successfully mobilized the media and community workers to inform families about the importance of vaccination.

But unfortunately these efforts have not been uniformly successful. Children of poor and uneducated parents remain at a disadvantage, as do children of Muslim parents, who remain underrepresented in child vaccination efforts compared to the children of Christian parents. The multivariate analysis presented here demonstrates that these religious disparities cannot be fully explained by a composition effect (based on the disparate socio-economic and demographic makeup of these two religious communities). Rather, these important differences are also due to ideological differences and/or diffusion effects arising from interactions within religious groups, even if the study was not able to separate these respective effects. In order to reduce these disparities in the future, it will be essential to work with religious groups and leaders to ensure that all children, regardless of religious background, are able to benefit from lifesaving public health measures.

\section{Acknowledgements}

The authors are grateful to the Wellcome Trust, which provided the financial support to create and maintain the Ouagadougou HDSS, on which this study is based (grant number WTO 8I993MA). The authors also wish to acknowledge the contributions of the field staff of the Ouagadougou HDSS and their important role in maintaining a good rapport with the study population.

\section{References}

Akoto, E 1990. "Christianisme et inégalités en matière de mortalité des enfants en Afrique noire" Population 45, (6) : 971-992.

BANQUE MONDIALE 2003. Santé et pauvreté au Burkina Faso : Progresser vers les objectifs internationaux dans le cadre de la stratégie de lutte contre la pauvreté. Washington, D.C : Banque Mondiale.

Baya, B 1998. "Instruction des parents et survie de l'enfant au Burkina Faso : cas de Bobo Dioulasso" Les dossiers du CEPED $48: 27 \mathrm{p}$.

Bayala-Ariste, L. L 2009. Monographie de la commune urbaine de Ouagadougou. Ouagadougou: Bureau Central du Recensement.

Becher, H, Muller, O, Jahn, A, Gbangou, A, KynastWolf, G, and Kouyaté, B 2004. "Risk factors of infant and child mortality in rural Burkina Faso" Bulletin of the World Health Organization 82: 265273.

BURKINA FASO, MINISTERE DE LA SANTE 2003. Revue approfondie du Programme Elargi de Vaccination. Ouagadougou : Ministère de la santé.

Caldwell, J.C 1979. "Education as a factor in mortality decline: an examination of Nigeria data" Population Studies 33, (3): 395-4I5.

Craney, T.A and Surles, J.G 2002. "ModelDependent Variance Inflation Factor Cutoff Values" Quality Engineering 14, (3): 391-403.

Durkheim, É 1897. Le suicide. Paris: Les Presses universitaires de France.

Farrar, D.E. and Glauber, R.R I967. "Multicollinearity in Regression Analysis: The Problem Revisited" The Review of Economics and Statistics 49, (1): 92107.

Fourn L., Haddad S., Fournier P. and Gansey, R 2009. "Determinants of parents' reticence toward vaccination in urban areas in Benin (West Africa)" BMC International Health and Human Rights 9, (Suppl I): 9 p.

Gemignani, R and Wodon, C 20I2. "How do households choose between health providers? Results from qualitative fieldwork in Burkina Faso" MPRA Paper 45375: 24 p.

Gyimah, S.O., Takyi, B.K. and Addai, I. 2006. "Challenges to the reproductive-health needs of African women: On religion and maternal health utilization in Ghana" Social Science \& Medicine 62: 2930-2944.

Gyimah, S.O. 2007. "What has faith got to do with it? Religion and child survival in Ghana" Journal of Biosocial Science 39, (6): 923-937.

Hummer, R.A, Rogers, R.G, Nam, C.B and Ellison, C. G 1999. "Religious involvement and U.S. adult mortality" Demography 36, (2): 273-285.

Institut National de la Statistique et de la Démographie (INSD) and ICF International 2012. Enquête Démographique et de Santé et à Indicateurs Multiples du Burkina Faso 2010. Calverton, Maryland, USA : INSD and ICF International.

Jegede, A. S 2007. "What Led to the Nigerian Boycott of the Polio Vaccination Campaign?" PLoS Medicine 4: 417-422.

Johnson, N. E 1993. "Hindou and Christian fertility in India: A test of three hypotheses" Social Biology 40, (I-2): 87-105.

Kennedy, R.E. 1973. "Minority Group Status and Fertility: The Irish" American Sociological Review 
38: 85-96.

Knodel, J, Rossarin Soottipong, G., Porntip S and Sara, P. 1999. "Religion and reproduction: Muslims in Buddhist Thailand" Population Studies 53, (2): 149-164.

McQuillan, K 2004. "When Does Religion Influence Fertility?" Population and Development Review 30, (I): 25-56.

Morgan, S.P., Stash S., Smith, H.L and Mason, K.O. 2002. "Muslim and Non-Muslim Differences in Female Autonomy and Fertility: Evidence from Four Asian Countries" Population and Development Review 28: 5I5-537.

Mosley, H.W and Chen, L.C. 1984. "An analytical framework for the study of child survival in Developing countries" Population and Development Review 10, (suppl): 25-45.

Ouédraogo, C. 1994. "Education de la mère et soins aux enfants à Ouagadougou" Les dossiers du CEPED n $27: 37 \mathrm{p}$.

Rossier, C., Soura, A., Baya, B., Compaore, G., Dabire, B., Dos Santos, S., Duthe, G., Gnoumou, B., Kobiane, J.F., Kouanda, S., Lankoande, B., Legrand, T., Mbacke, C., Millogo R., Mondain, N., Montgomery, M., Nikiema, A., Ouili, I., Pison, G., Randall, S., Sangli, G., Schoumaker, B and Zourkhaleini, Y 20I2. "The Ouagadougou Health and Demographic Surveillance System" International Journal of Epidemiology 4I, (3): 658666.

Soura, B.A 2009. Analyse de la mortalité et de la santé des enfants à Ouagadougou : inégalités spatiales, effets individuels et effets contextuels. Louvain-la Neuve : Presse Universitaire de Louvain.
Takyi, B.K and Addai, I. 2002. "Eects of ethnicity on the onset of parenthood in a developing Country: The early 1990s" Journal of Comparative Family Studies 33: 5I-7I.

Tfaily R., Khawaja, M. and Kaddour, A 2009. Christian - Muslim Fertility Differences in Poor Settings in Greater Beirut, Lebanon. Paper presented in the $X X V I^{\mathrm{e}}$ IUSSP International Population Conference, September 27-October 2 2009, Marrakech, $36 \mathrm{p}$.

Turrell, G. 2002. "Reducing socioeconomic health inequalities: issues of relevance for policy" New South Wales Public Health Bulletin 13: 47-49.

UNITED NATIONS DEVELOPMENT PROGRAMME (UNDP) 20I3. Human Development Report 2013. The Rise of the South: Human Progress in a Diverse World. New York: UNDP.

United Nations International Children's Emergency Fund (UNICEF) 2004. Instaurer la confiance en la vaccination : Créer un partenariat avec les autorités et associations religieuses. New York : UNICEF.

Van Poppel, F., Schellekens, J and Liefbroer, A. C 2002. "Religious Differentials in Infant and Child Mortality in Holland" Population Studies 56, (3): 277-289.

Yeatman, S.E. and Trinitapoli, J. 2008. "Beyond denomination: The relationship between religion and family planning in rural Malawi" Demographic Research 19, (55): 1851-1882.

Zhang, L. 2008. "Religious affiliation, religiosity, and male and female fertility" Demographic Research 18, (8): 233-262. 